\title{
ЗАЩИТА ПРАВ МНОГОДЕТНЫХ СЕМЕЙ В УСЛОВИЯХ НЕСОВЕРШЕНСТВА РЕГИОНАЛЬНОГО ЗАКОНОДАТЕЛЬСТВА
}

\author{
Лилия Владимировна БОРИСОВА, \\ кандидат юридических наук, доцент, \\ старший научный сотрудник сектора \\ гражданского права, гражданского \\ и арбитражного процесса Института \\ государства и права Российской академии наук \\ E-mail: lilya-borisova@yandex.ru
}

\begin{abstract}
Аннотация. На основании анализа материалов судебной практики доказано, что сведения о регистрации членов многодетной семьи по месту жительства могут по общему правилу свидетельствовать о месте их жительства, пока не предоставлены доказательства, подтверждающие место жительства по иным основаниям. При этом во внимание могут быть приняты длительность проживания в жилом помещении, оплаченные счета за коммунальные услуги, договор найма жилого помещения, решение суда об установлении факта проживания на определенной территории и др.

Ключевые слова: место жительства; место регистрации по месту жительства; многодетная семья; социальная подлержка.
\end{abstract}

\section{PROTECTION OF THE RIGHTS OF LARGE FAMILES IN CONDITIONS IMPERFECTION OF REGIONAL LEGISLATION}

\author{
Lilia Vladimirovna BORISOVA, \\ Candidate of Legal Sciences, Associate Professor, \\ Senior Researcher of the Sector of civil law, \\ Civil and Arbitration Process \\ of the Institute of State and Law, Russian Academy of Sciences \\ E-mail: lilya-borisova@yandex.ru
}

\begin{abstract}
Based on the analysis of the materials of judicial practice, it has been proved that information on the registration of members of a large family at the place of residence can, as a general rule, indicate their place of residence, until evidence is provided confirming the place of residence on other grounds. In this case, the duration of residence in a residential building, paid utility bills, a rental agreement, a court decision on establishing the fact of residence in a certain territory, etc. can be taken into account.

Keywords: place of residence; place of registration at the place of residence; large family; social support.
\end{abstract}

$\mathrm{B}$ современной России особое значение в реализации гарантированных Конституцией Российской Федерации прав придают такой ценности, как право граждан на место жительства (ст. 27 Конституции Р $\left.\Phi^{1}\right)$.

Согласно действующему в настоящее время региональному законодательству, с точ- ным определением места жительства связано предоставление многодетным семьям различного рода социальных услуг. Так, в постановлении Правительства Московской области от 12 декабря 2017 г. № 1029/45 “Об утверждении порядка выдачи удостоверения многодетной семьи" (далее - Порядок выдачи удостоверения многодетной семьи) прямо 
указано, что для получения удостоверения многодетной семьи заявитель представляет в территориальное структурное подразделение Министерства социального развития Московской области или в МФЦ документы, подтверждающие место жительства заявителя, супруга (супруги) заявителя, детей, достигших 14 лет, в Московской области (абз. 5 п. 6). Место жительства на территории Московской области необходимо для бесплатного предоставления многодетным семьям земельных участков $^{2}$, постановки на учет в качестве нуждающихся в жилых помещениях, предоставляемых

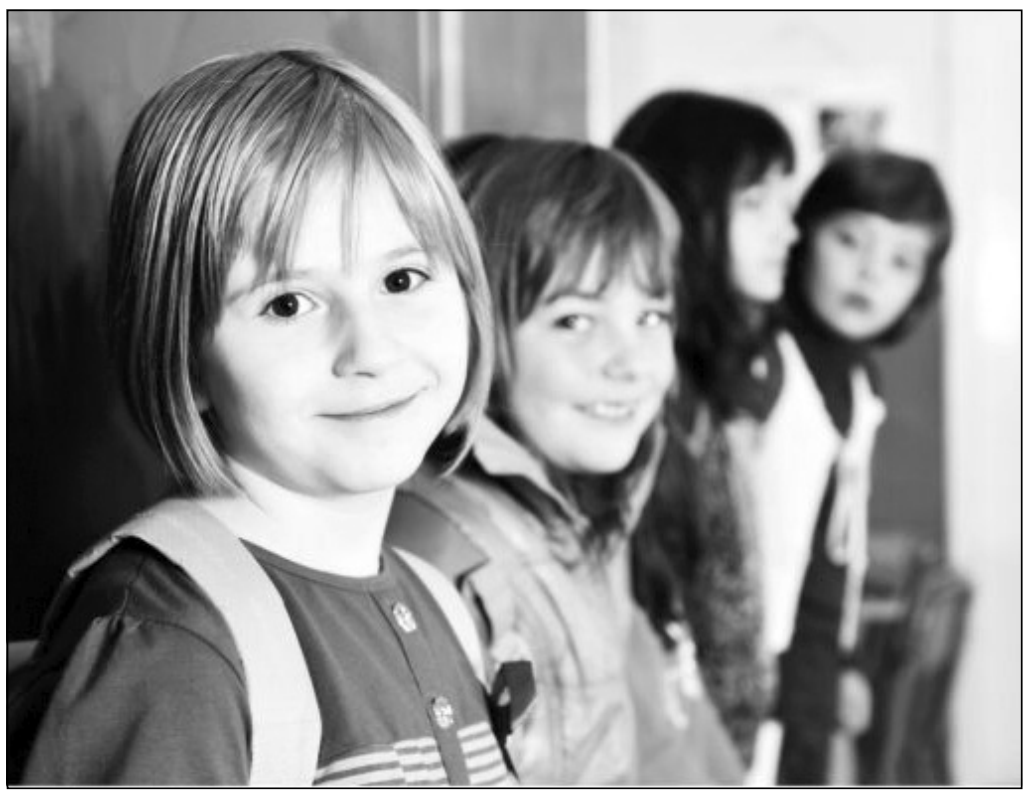
по договорам социального найма ${ }^{3}$, и др.

Правоприменительная практика свидетельствует о том, что в большинстве случаев государственные органы связывают место жительства членов многодетных семей с местом их регистрации по месту жительства, основываясь на положении ст. 2 Закона РФ от 25 июня 1993 г. № 5242-I «О праве граждан Российской Федерации на свободу передвижения, выбор места пребывания и жительства в пределах Российской Федерации" (далее - Закон о праве граждан РФ на свободу передвижения). В данной правовой норме приведены основные понятия, которые используются в целях указанного нормативного правового акта, к их числу отнесено и понятие места жительства, в содержании которого подчеркивается, что это жилое помещение, где гражданин зарегистрирован по месту жительства. Руководствуясь данным определением государственные органы отказывают в реализации прав многодетных семей в случае, если кто-либо из ее членов (дети, супруг или супруга) не имеет регистрации по месту жительства в регионе предоставления услуг.

Так, Сергиево-Посадским управлением социальной защиты населения Министерства социального развития Московской области было отказано заявителю Ч.Я. в выдаче удостоверения многодетной семьи ввиду отсутствия у детей Ч.Я. регистрации на территории Московской области. Законность отка-

за сотрудники управления связали с определением места жительства детей заявителя с местом их регистрации в г. Абакане (Республика Хакассия), сославшись на положениест. 2 Закона о праве граждан РФ на свободу передвижения ${ }^{4}$.

Действительно, исходя из дефиниции понятия места жительства в ст. 2 Закона о праве граждан РФ на свободу передвижения, а также Правил регистрации и снятия граждан Российской Федерации с регистрационного учета по месту пребывания и по месту жительства в пределах РФ, утвержденных постановлением Правительства РФ от 23 апреля 1996 г. № 512 (далее - Правила № 512), место жительства гражданина, по общему правилу, должно совпадать с местом его регистрации по месту жительства. Как указано в абз. 2 п. 1 Правил № 512, регистрационный учет устанавливается в целях обеспечения необходимых условий для реализации гражданами своих прав и свобод, а также исполнения ими обязанностей перед другими гражданами, государством и обществом.

Тем не менее, полагаем, что в гражданско-правовом значении понятие "место жительства" не может быть сведено только к месту регистрации членов многодетной семьи по месту жительства.

Во-первых, понятие места жительства, в соответствии со ст. 2 Закона о праве граждан РФ на свободу передвижения, дано ис- 


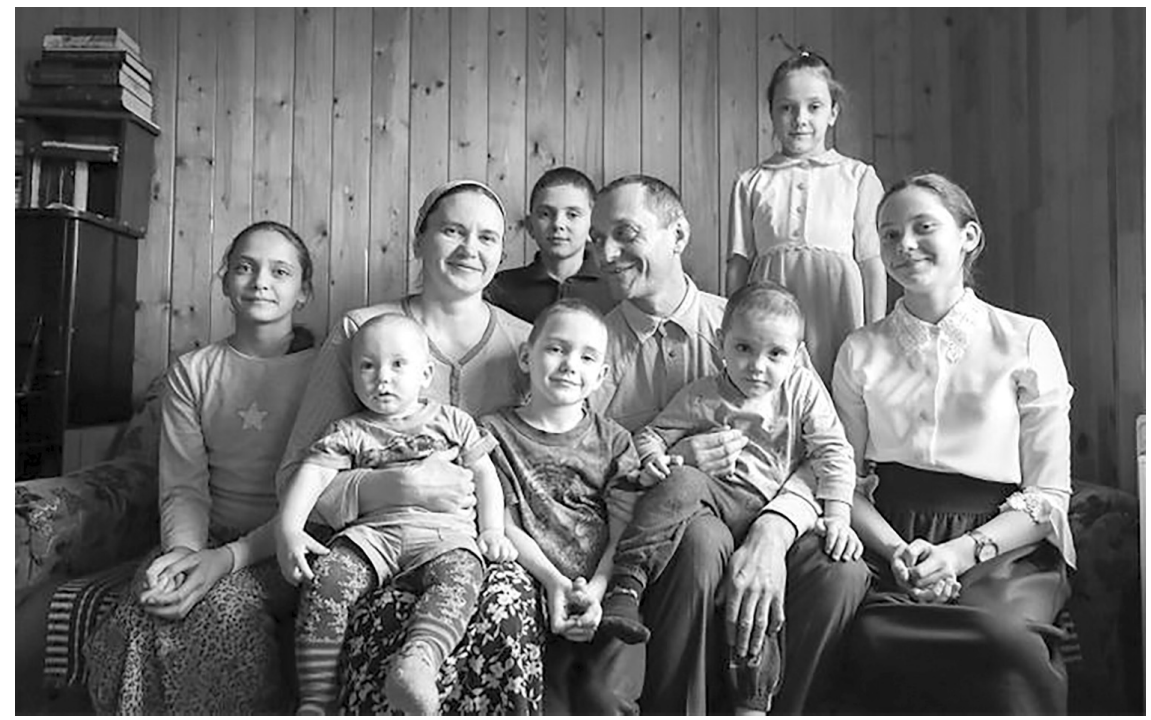

помещения, акт о вселении, оплаченные счета за коммунальные услуги, решение суда об установлении факта проживания гражданина на определенной территории и др. ${ }^{7}$ В определении Верховного Суда РФ от 22 июня 2005 г. № 93-Г05-7, в частности, указано, что "регистрация не входит в понятие "место жительства" и является лишь одним из обстоятельств, отражающих факт нахождения гражданина по месту жительства или пребывания» ${ }^{8}$.

ключительно для целей применения данного Закона.

Во-вторых, регистрация сама по себе не может служить условием реализации прав и свобод граждан, предусмотренных Конституцией РФ, законами РФ и законами республик, входящих в состав РФ (ст. 3 Закона о праве граждан РФ на свободу передвижения). На это неоднократно указывал Конституционный Суд РФ ${ }^{5}$.

В-третьих, понятие "место жительства" определяется не только Законом РФ о праве граждан РФ на свободу передвижения, но и иными правовыми нормами, в частности п. 1 ст. 20 ГК РФ, согласно которому местом жительства признается место, где гражданин постоянно или преимущественно проживает. Существующая судебная практика сводится преимущественно к пониманию под постоянным местом жительства места, где гражданин обосновался в силу сложившихся обстоятельств. Под местом преимущественного проживания понимается место, где гражданин проживает больше, чем в других местах, либо вынужден находиться в силу сложившихся обстоятельств ${ }^{6}$.

В-четвертых, обобщение материалов судебной практики свидетельствует о том, что место жительства гражданина может быть подтверждено различными юридическими фактами, не обязательно связанными с регистрацией. Во внимание могут быть приняты длительность проживания членов многодетной семьи в жилом помещении, договор найма жилого
С указанной точки зрения постановления судов, основанные на подтверждении места жительства гражданина не только актом регистрации по месту жительства, но и иными основаниями, представляются более обоснованными.

К примеру, по делу, рассмотренному Ступинским городским судом Московской области, истец М. обратилась с заявлением в суд об установлении факта проживания ее многодетной семьи на территории Московской области и признании за ней права на бесплатное получение земельного участка. Истец указала, что с 2011 г. зарегистрирована по месту жительства в г. Москва, хотя с 2010 г. фактически всегда проживала со своей семьей в г. Ступино у своих родителей или у родителей мужа.

Суд признал за истцом право постановки на учет в целях предоставления земельного участка, подтвердив проживание ее многодетной семьи на территории Московской области на основании следующих доказательств: (1) истец М. является многодетной матерью троих несовершеннолетних детей, зарегистрирована на территории Ступинского района Московской области; (2) справками из детской поликлиники и женской консультации в г. Ступино подтверждается, что М. состояла на учете по беременности и на учете с детьми с момента их рождения; (3) справкой их лицея подтверждается обучение детей истца М. в школе № 12 г. Ступино; (4) из копии трудовой книжки ист- 
ца М. следует, что она с 2007 г. осуществляла трудовую деятельность в организациях г. Ступино; (5) справкой главы Управы района Чертаново Южное г. Москвы подтверждается, что истец на учете для получения земельного участка не состояла ${ }^{9}$.

Из приведенного следует, что регистрация членов многодетной семьи по месту жительства может не совпадать с местом их жительства и не может служить условием реализации прав на получение социальной поддержки. Исходя из этого, полагаем, что при в приведенном примере при решении вопроса о выдаче (отказе в выдаче) удостоверения многодетной семьи в Московской области, определяя место жительства заявителя, его супруга и детей, достигших 14-летнего возраста (п. 6 Порядка выдачи удостоверения многодетной семьи), государственному органу следовало в качестве общего правила исходить из данных о месте регистрации членов многодетной семьи по месту жительства в Московской области. Однако в случае если заявителем предоставлены документы, подтверждающие место жительства по иным основаниям, они должны быть приняты во внимание и учтены при вынесении соответствующего решения. Именно такой подход позволит обеспечить защиту прав многодетных семей на получение социальной поддержки в условиях несовершенства регионального и иного законодательства.

\footnotetext{
${ }^{1}$ Конституция Российской Федерации: принята всенародным голосованием 12 декабря 1993 г. (с учетом поправок, внесенных законами РФ о поправках к Конституции Российской Федерации от 30 декабря 2008 г. № 6-ФКЗ, от 30 декабря 2008 г. № 7-ФКЗ, от 5 февраля 2014 г. № 2-ФКЗ, от 21 июля 2014 г. № 11 ФКЗ, от 14 марта 2020 г. № 1-ФКЗ // Российская газета. 1993. 25 декабря; Официальный интернетпортал правовой информации www.pravo.gov.ru
}

2 Статьи 3, 4 Закона Московской области от 1 июня 2011 г. № 73/2011-О3 «О бесплатном предоставлении земельных участков многодетным семьям в Московской области" (с изм. на 2 марта 2021 г.) // Ежедневные новости. Подмосковье. 2011.4 июня.

${ }^{3}$ Статья 1 Закона Московской области от 21 июля 2017 г. № 140/2017-О3 «О внесении изменений в Закон Московской области «О порядке ведения учета граждан в качестве нуждающихся в жилых помещениях, предоставляемых по договорам социального найма" // Официальный сайт Правительства Московской области www.mosreg.ru

${ }^{4}$ Определение Первого Кассационного Суда общей юрисдикции от 25 января 2021 г. по делу № 88-693/ 2021 [Электронный ресурс] //Режим доступа: http:// www.consultant.ru/

${ }^{5}$ См., например, постановления КС РФ от 24 ноября 1995 г. № 14-П, от 4 апреля 1996 г. № 9-П, от 15 января 1998 г. № 2-П, от 2 февраля 1998 г. № 4-П, от 2 июня 2011 г. № 11 -П, от 30 июня 2011 г. № 13-П; определения от 13 июля 2000 г. № 185-О, от 6 октября 2008 г. № 619-О-П, от 13 октября 2009 г. № 1309-О-О и др. [Электронный ресурс] // Режим доступа: http:// www.consultant.ru/

${ }^{6}$ См., в частности, апелляционные определения Московского городского суда от 24 июля 2013 г. по делу № 11-23418/13, СК по гражданским делам ВС Кабардино-Балкарской Республики от 5 ноября 2015 г. по делу № 33-1305/2015; определения СК по гражданским делам Свердловского областного суда от 25 ноября 2015 г. по делу № 33-17335/2015, СК по гражданским делам Краснодарского краевого суда от 9 февраля 2016 г по делу № 33-1841 / 2016 и др. [Электронный ресурс] // Режим доступа: http:// www.consultant.ru/

${ }^{7}$ См, например, определения СК по гражданским делам Верховного Суда РФ от 24 февраля 2015 г. по делу № 47-КГ14-13, Четвертого кассационного суда общей юрисдикции от 6 февраля 2020 г. № 88-2970/ 2020 по делу № 2-675/2019; постановление Арбитражного суда Центрального округа от 3 апреля 2019 г. № Ф10-674/2019 по делу № A14-9567/2018 и др. [Электронный ресурс] // Режим доступа: http:// www.consultant.ru/

${ }^{8}$ Режим доступа: http://www.consultant.ru/

${ }^{9}$ Решение Ступинского городского суда Московской области от 13 мая 2016 г. № 2-1076/2016 [Электронный ресурс] // Режим доступа: http://www. consultant.ru/ 